\title{
Nurses' Clinical Practice in Primary Care: a Process Under Construction
}

\author{
Silvia Matumoto ${ }^{1}$ \\ Cinira Magali Fortuna ${ }^{1}$ \\ Lauren Suemi Kawata ${ }^{2}$ \\ Silvana Martins Mishima ${ }^{3}$ \\ Maria José Bistafa Pereira ${ }^{4}$
}

This study aims to present the re-signification process of the meanings of nurses' clinical practice in primary care from the perspective of extended clinic and permanent education. An intervention research was carried out with the approval of an ethics committee. Nine nurses participated in reflection groups from September to December 2008 in Ribeirão PretoSP-Brazil. The redefinition process of the meanings proposed by the institutional analysis was mapped. The results point out that the nurses perceive differences in clinical work, by acknowledging the sense of user-centered clinical practice; daily limits and tensions and the need for support from managers and the team to deal with users' problems and situations. They identify the necessity to open space in the schedule to do that. It was concluded that nurses' clinical practice is being consolidated, and that collective analysis processes permit learning and the reconstruction of practices.

Descriptors: Public Health Nursing; Primary Health Care; Learning; Work; Health Knowledge, Attitudes; Practice.

\footnotetext{
${ }^{1}$ RN, Ph.D. in Nursing, Professor, Escola de Enfermagem de Ribeirão Preto, Universidade de São Paulo, WHO Collaborating Centre for Nursing Research Development, SP, Brazil. E-mail: Silvia - smatumoto@eerp.usp.br, Cinira - fortuna@eerp.usp.br.

${ }^{2}$ RN, Doctoral Student, Escola de Enfermagem de Ribeirão Preto, Universidade de São Paulo, WHO Collaborating Centre for Nursing Research Development, SP, Brazil. Assistant Professor, Universidade Federal de Uberlândia, MG, Brazil. E-mail: Isuemi@hotmail.com.

${ }^{3}$ RN, Ph.D. in Nursing, Full Professor, Escola de Enfermagem de Ribeirão Preto, Universidade de São Paulo, WHO Collaborating Centre for Nursing Research Development, SP, Brazil. E-mail: smishima@eerp.usp.br.

${ }^{4}$ RN, Ph.D. in Nursing, Associate Professor, Escola de Enfermagem de Ribeirão Preto, Universidade de São Paulo, WHO Collaborating Centre for Nursing Research Development, SP, Brazil. E-mail: zezebis@eerp.usp.br.
} 


\section{A prática clínica do enfermeiro na atenção básica: um processo em construção}

Este estudo objetivou apresentar o movimento de ressignificação dos sentidos da prática clínica de enfermeiros, na atenção básica, em processo de qualificação, na perspectiva da clínica ampliada e educação permanente. Realizou-se pesquisa-intervenção aprovada em comitê de ética. Nove enfermeiros participaram do grupo de reflexão, de setembro a dezembro de 2008, em Ribeirão Preto, SP, Brasil. Cartografou-se o processo de ressignificação dos sentidos proposto pela análise institucional. Os resultados apontam que os enfermeiros percebem diferenças no fazer clínico, ao reconhecer o sentido da clínica centrada no usuário, os limites e tensões do cotidiano e a necessidade de respaldo da gerência e da equipe para o manejo de situações e problemas dos usuários. Identificou-se a necessidade de abrir espaço na agenda para realizá-la. Conclui-se que a prática clínica do enfermeiro vem se consolidando e que processos coletivos de análise possibilitam aprendizagens e reconstrução das práticas.

Descritores: Enfermagem em Saúde Pública; Atenção Primária à Saúde; Aprendizagem; Trabalho; Conhecimentos, Atitudes e Práticas em Saúde.

\section{La práctica clínica del enfermero en la atención básica: un proceso en construcción}

Este estudio tuvo por objetivo presentar el movimiento de dar nuevo significado a los conceptos de la práctica clínica de enfermeros en la atención básica en proceso de calificación en la perspectiva de la clínica ampliada y educación permanente. Realizamos una investigación-intervención aprobada en comité de ética. Nueve enfermeros participaron del grupo de reflexión, de septiembre a diciembre de 2008, en Ribeirao Preto, SP, en Brasil. Cartografiamos el proceso dar nuevo significado a los conceptos propuesto por el análisis institucional. Los resultados apuntan que los enfermeros perciben diferencias en el quehacer clínico, al reconocer el sentido de la clínica centrada en el usuario, los límites y tensiones de lo cotidiano y la necesidad de obtener soporte de la administración y del equipo para el manejo de situaciones y problemas de los usuarios. Identifican que necesitan abrir espacio en la planificación para realizarla. Concluimos que la práctica clínica del enfermero se viene consolidando y que los procesos colectivos de análisis posibilitan aprendizajes y la reconstrucción de las prácticas.

Descriptores: Enfermería en Salud Pública; Atención Primaria de Salud; Aprendizaje; Trabajo; Conocimientos, Actitudes y Práctica en salud.

\section{Introduction}

We study nurses' clinical practice in Brazilian primary health care, considered as a social practice, i.e. performed based on each historical moment's social needs and constituted and transformed in the dynamics of relations with other practices ${ }^{(1)}$.

In the 1970's, the period of "Health Programming" in São Paulo State, health care was structured through programs and nurses worked at health centers, preferable performing management, supervision, training, control and nursing staff coordination actions ${ }^{(2)}$. In the 1980's and 1990 's, the expansion of service access and the proposal to articulate individual medical care with collective health actions predominantly resulted in emergency care-like actions. Nurses' work was directed at the organization and maintenance of service infrastructure for medical care, the organization of nursing work and some collective health actions, such as vaccination and epidemiological surveillance ${ }^{(1,3)}$. 
The implantation process of the Unified Health System (SUS), guided by its principles and by the health concept as social production constitutes the re-signification context of nurses' primary health care work. Nursing tasks include not only health and nursing service management and organization, but also clinical actions in direct user care. Nevertheless, nursing practices have been more centered on emergency care and the production of procedures ${ }^{(1)}$. Therefore, nurses' clinical practice needs to be reviewed with a view to comprehensiveness and problem-solving ability, and needs to be user-centered, considering users' singularity and respecting the autonomy of the subject who needs care $^{(4-5)}$

The function of nursing work is to deliver care to healthy or sick individuals, families and communities, performing activities to promote, maintain and recover health, thus contributing to the implementation and consolidation of the SUS ${ }^{(5)}$

The Ministry of Health puts forward primary health care as the axis to organize the health system and Family Health (FH) as the priority strategy to promote changes in health practices, oriented by the principles of the SUS ${ }^{(4)}$.

For nursing, the Family Health Strategy represents a possibility to reorient its actions towards users' health needs and not to rationalize medical professionals' work. Nursing practice in this perspective is directed at its specific goal, which is nursing care ${ }^{(6)}$.

By performing their social role as caregivers, nurses experience the tensions characteristic of the production of health acts - the production of procedures versus the production of care. They establish intercessory relations with users and need to incorporate light technologies ${ }^{(7)}$ into their toolbox, such as listening, welcoming, bonding, accountability and skills to deal with the high levels of uncertainty intrinsic in this work. Moreover, in the role of therapeutic project managers, nurses experience the tensions characteristic of the articulation between different knowledge cores and responsibilities of different professionals involved in the therapeutic project. That is, they experience the tension between teamwork versus more individualized specialized work ${ }^{(7)}$.

Thus, we synthesize nurses' work in primary health care in the double care and management dimension: directed at the individual - nursing care production and management of therapeutic projects - and at the collective - monitoring of the population's health situation, nursing team and health service management for care production. Management actions predominate among nursing practices at basic health units ${ }^{(8)}$; in the care dimension, nurses themselves acknowledge nursing consultations as important in clinical practice ${ }^{(9)}$, but these mainly remain within the logic of individual and curative clinical care, without broadening the understanding of the health-disease process as social production ${ }^{(10-11)}$. We believe that this research can contribute to expand knowledge on nurses' care dimension.

The amplified clinic appears as a tool for health work processes to turn to user-centered care production, including, besides the illness, the subject in his/her context and the collective sphere. The care object, means and targets are amplified. It aims for cure and the relief of suffering, as well as the development of people's autonomy to deal with their problems and concrete living conditions, through the predominant use of light technologies and dialogued construction between workers, users and families and health teams ${ }^{(12-13)}$.

Permanent Health Education ${ }^{(14)}$ (PHE) can be a strategy to qualify nurses for the amplified clinic. PHE operates significant learning processes in which workers themselves analyze their work, producing knowledge on this practice, identifying strengths and gaps, which thus mobilize the search for new knowledge.

PHE and the micro-politics of the health work process use institutional analysis concepts, which facilitate the understanding of the way health work is produced in its inherent objective and subjective aspects.

Exploring nurses' clinical practice as a research problem takes us to the institutional field, to the way society defines and acknowledges what nursing is, how its practice should be, setting functioning rules and standards. We enter the field of professional identified, of established segmentarities. We examine its limits, that is, what is a task and responsibility of this professional group and each nursing team category or not, outlining a field of conflicts and disputes in political, legal, judicial, education practices, in short, disputes between social classes, between the different professions and segments of society and which also dispute the way this same society maintains itself(15).

Society's functioning is structured through a global political system of segmentarity lines. The most linear lines determine code and territory and imply, for example, a power device in professional activities, define ways to move among the segments, constructing a hierarchy and a bureaucracy that become hardly flexible. At the same time, other kinds of lines, called circular, design the segmentarity centered around one point, such as the physician's work for example, around which the 
other categories' circles revolve, and likewise determine operating modes, with little flexibility. A third kind of lines is present all the time in daily reality and can hardly be perceived: these are the escape lines, emerging when health work is produced, intertwined with the other lines, opening room to break with established modes, daily routines, opening room to do things differently. The escape lines provoke estrangements due to the rupture with certainties, leaving people who perceive them in a state called deterritorialization, when one can no longer return to the immediately preceding state, as one has already turned into something else, something happened, the new has occurred ${ }^{(16)}$.

At health services, the above concepts are subsumed in a tense and conflicting daily reality, which is predominantly produced in the maintenance of traditional work modes, at the same time as fragile movements occur to invent new practices.

In our study, we focus on nurses' clinical practice and their core competency and responsibility - nursing care - questioning: How is nurses' clinical practice characterized in primary health care? Which would be the difficulties faced? How can nurses' clinical practice be amplified and qualified in primary health care?

Our goal is to present the redefinition movement of the senses of some nurses' clinical practice in primary health care, in the process of qualifying this practice with a view to the amplified clinic.

\section{The methodological route}

The research problem outlines a qualitative methodological approach. We developed an intervention research, which is a participatory research mode. The different participatory research approaches share the participation of social groups in the understanding of their reality and the search for solutions to their problems.

"In the institutional analysis proposal (...) the research moment is the moment of theoretical production and, mainly, of producing the object and the person who knows it; the research moment is the moment of intervention, (...) the motto of intervention research is to question the 'sense' of the action"(17).

Inquiring about the "meaning" attempts to recognize the action, explores the way the team that produces the action functions. This recognition aims to generate an intervention that makes a difference, a new positioning of meaning and goal beyond return, in the perspective of producing a singular collective movement of appropriation and invention of life.
The intervention research was carried out through a reflection group $^{(18)}$, involving nine nurses from the primary health care network in Ribeirão Preto. Five of them worked in the Family Health strategy, three in the Community Health Agent strategy and one at a traditional Basic Health Unit (BHU). We did not distinguish the subjects according to the health unit's care model, with a view to a broader exploration of the nurses' clinical practice in primary health care. Eight two-hour meetings were held between September and December 2008. The meetings were recorded and transcribed. A team with two co-coordinators and one silent observer coordinated the group. A specialized supervised the team's group work.

The nurses' movements were mapped and analyzed to apprehend their work process, in a significant learning experience, to identify what they call clinical practice and perceive difficulties and potentials. The analytic process itself allowed the nurses to amplify the understanding of their actions, as well as to review themselves in clinical primary health care practice, thus constituting a significant learning process in PHE.

In institutional analysis, mapping is a methodological tool in intervention research, constructed based on experience, composing a design that follows the transformation movements of meanings. These are singular experiences in which something ceases to make sense, at the same time as new worlds of references are created $^{(19)}$

In the results section, the group meetings are identified with the corresponding meeting number. In the dialogue excerpts, the nurses are identified as " $\mathrm{N}$ ", followed by a number from 1 to 9 .

Approval for the study was obtained from the Research Ethics Committee at the University of São Paulo at Ribeirão Preto College of Nursing (Process No 0832/2007). All participants signed the informed consent term, in compliance with National Health Council Resolution 196/96.

\section{Presenting results}

The research group constituted a space for the nurses' PHE, involving exchanges and collective analyses on their clinical practice, through self-analysis of daily reality, in which the what, why, how and for what reason they do the work were recognized. Thus, they analyzed its meaning and limits, by reviewing what needed to be changed(18).

We will now present some of the themes addressed at different moments when the study subjects recognized 
and discovered new meanings. The titles of these moments highlight their most significant aspects.

\section{Theme 1 - What the nurses call clinical practice in primary health care}

The nurses consider the following as clinical activity: welcoming practices; nursing consultation (more frequently to collect pap smear, prenatal and puerperal, family planning, childcare, hypertensive and diabetic patients, mental health); home visit/care, group work; and, as indirect clinical activity, orientation to nursing auxiliaries and community health agents and support to physicians in care activities.

They mention that nurses' clinical practice in primary health care has been developing in function of legal requirements for professional practice ${ }^{(20)}$.

The analysis takes the group to another level in understanding this practice: the model they know is that of the medical consultation, in which they find themselves reproducing the hegemonic model.

The meeting aroused my reflections based on the conversation here (...) Because we don't manage to do it... (...) When the nurse is called for a direct care task (...) we turn to the known hegemonic model, which is medical clinical practice, whose structure is already known, right? At what time we approach that clinic or take distance from that clinic. Yes, I'm thinking about that. (...) Because we are constructing. (Meeting 2)

The nurses find their own way of habitual actions strange, an estrangement needed to redefine the meanings, later permitting the appropriation of the amplified clinic perspective, opening breaches for new ways to do their work.

\section{Theme 2 - Distinguishing clinical practice in search of a definition}

The nurses identify differences in their attendance, recognizing the existence of "clinical care practice" and the "pseudo-medical consultation":

N1: I think we also need to discuss (...) about nurses starting to perform the clinical care role more. What's that? (...) the nurse is going to do clinical practice, what's that practice?

N2: (...) each person understands it in her own way.

N1: Our clinical practice has to be clinical care practice. That clinical care practice makes me feel at ease, but the clinical nursing practice that is a pseudo-medical consultation, I have been discussing that for years. (...) (Meeting 1)

Although they do not define the "pseudo-medical consultation", it is opposed to clinical care practice, which makes room to listen to people's needs, not remaining limited to the formal structure of a consultation, focusing on the sick person, but broadening by looking at the family and the context the person lives in.

And, in this movement, the group attempts to clarify what the amplified clinic is:

N3: (...) the proposal of the amplified clinic, which is a different, distinguished clinical practice. Because then we won't just look at the biological, pathological individual, treat and prescribe. I think it involves the therapeutic project with actions that go far beyond the disease and the individual, but look at the collective, look at the person's life context. It means working so that (...) the person himself can control and influence the determining factors of his illness, of his healthdisease process. So (...) I think that our clinical practice closely approaches the amplified clinic proposal. Where we will transform the subjects. (...) we are going to involve the family, the context (...) (Meeting 2)

In the reflection, the group reaches a formulation of clinic from the amplified perspective that is similar to what has been proposed as a tool to change the care model ${ }^{(12,21)}$. At the same time, the group discusses and reflects on its practice.

\section{Theme 3 - The structural and organizational conditions of health units}

The nurses identify disparities in structural conditions at different health units with a view to clinical practice. Few units have an adequately equipped consultation room at the nurses' exclusive disposal; at most unit, independently of the care model (FH, CHAS or traditional), they need to await the end of medical attendance to use the room, compromising the supply of nursing services.

They also appoint the lack of some aspects in service organization, needed for nursing actions to be performed, such as the support of a reception service during some hours, the withdrawal of patient files and local management support.

N3:(...) when you talk about amplified clinic (...) seeing, hearing, feeling, subjectivities, amplifying listening, making room for all that. But, at the same time, it's conflicting. (...) we don't have support, structure to manage to put the clinic in practice they so much desire.... (...) When the time has come to do things, sometimes, you don't have the hard technologies, the structure, the consultation room, the table, the chair, the stretcher for you to try and put the amplified clinic in practice. (...) I don't have a space for listening, to listen to the patient, to receive the patient. (...) (Meeting 1 ).

The nurses report that there is no technical support for clinical nursing practice, no specific technical supervision. They use protocols from the Ministry of 
Health or other cities, although some are not officially adopted by the Municipal Health Secretary. These do not always attend to the needs though.

Thus, some structural and organizational conditions at the health units are appointed as daily difficulties for clinical nursing practice in primary health care, and reveal that, although actions like the nursing consultation figure among nursing tasks ${ }^{(4)}$ and constitute an exclusive responsibility(20), some health units' architecture and organizational conditions do not favor the supply of this care, as they have historically been oriented towards physician-centered health care.

\section{Theme 4 - Tensions and limits in clinical nursing practice}

The problematization about the limits of clinical practice makes the nursing group acknowledge some daily tensions through the self-analysis process.

The nurses identified technical references and Nursing Council standards for professional exercise as limits. They perceive that these have the simultaneous meaning of limit and orientation for clinical work:

N1: The parameter is still what I have already studied as the nursing consultations, what I see which is the technical legal limit. (...)

N4: I think I've reached my limit, from this point onwards it is no longer mine. (...) And, according to COREN's legal limit, then I'm going to discuss it with the doctor (Meeting 1).

The group also identified other health team professionals' work as a limit, mainly the physician's.

N2: I went there to collect the pap smear. There was an injury. For me, that, it didn't seem HPV, it didn't seem a genital wart, it didn't seem a malign condition, but it stopped, my clinical ability ended. I had to maintain the girl, remove the speculum, ask her to wait, and I went to get a person able to discern on this aspect of the limit. (Meeting 2)

The group members mention that the nonrecognition of nurses' clinical work in the organization and management sphere bothers them. They report that, in daily reality, nurses' work is remembered to replace what the physician does not want or does not like to do, or as a way to expand the coverage, and not due to the work itself.

They appoint that the users' recognition is different as, when they experience clinical nursing attendance, they identify the reference point for their care, which entails great satisfaction and makes their work meaningful.

N2: Many people get here and... I want to talk to the nurse, and that arouses jealousy, envy. Let them. (Meeting 1)
The presented tensions demonstrate that the constitution process of nurses' clinical work as a social practice is a source of disputes, involving health professionals, users and managers ${ }^{(7)}$.

Likewise, amplified clinical practice arouses great tension in nurses when producing care. This tension results from the fears, hesitance, uncertainties, characteristic of the subjective situations and the implications deriving from bonding.

N1: (...) your patient, you don't know his name and surname. We do.

N6: (...) A patient from the area. The community agent arrives saying that the daughter who was taking care said: my mother is like this. The girl was blunted, saying: I'm not going to eat, I'm gonna die, I don't want to live. (Meeting 1)

This clinical practice entails non-specific demands for nurses(13), for which they do not always have the knowledge and technical skills; thus, they find themselves in unknown territory, awaiting the invention of new ways to cope with health problems. The non-specific and notknowing are associated with the dependence on other team members work, which highlights the nurses' family tensions even further.

The nurses face this picture of tensions, complexity and lack of knowledge in different ways. Some say they are willing to construct this new way of doing, while others flee from clinical work, and yet others are not clearly willing to do it.

N4: There is a protocol nobody uses either. For about 15 years, there were basic health units with a colleague who used to flee from the vaccination room... and everything is protocoled as conduct there.... (Meeting 1)

If, on the one hand, the group acknowledges that there are knowledge mastering situations, which permits consistently arguing and sustaining a position on a given viewpoint and/or conduct, on the other, however, they perceive that there are situations of not-knowing and that an attitude of humility and active search, by informing themselves with the competent professional for this purpose, can be problem-solving. In these cases, in general, they turn to the physicians, but this bothers them, due to the feeling of dependence, of obligatory accountability, updating the historical dispute between the two professional categories.

N7: Some things are difficult for me, but I think we need to be humble like, to be able to seek (...) to help me. I seek. (Meeting 1)

The nurses' bother very probably derives from the medical category's attitude of seeing themselves as a service client, as observed in the hospital work process ${ }^{(22)}$. 
The physicians expect that the service will guarantee the "inputs" (tests, drugs, including nursing work) for them to do their job. Hence, there is no attitude to construct teamwork, but attitude to take hold of the other person's work, which causes bother.

Amidst this discussion about the bother caused by depending on the physician's work, another possibility of looking at the issue emerges:

I find it somewhat prejudiced and a little (...) that it discredits our work because of that. Why can I conclude his consultation, do a post-consultation, provide the orientations, and why can't he give the prescription for my consultation? (Meeting 2)

This statement appoints a different angle. Traditionally, nursing "completes" medical care in the post-consultation. The new meaning that is appointed breaks with the hegemonic form: the physician as well, in turn, "would complete" the nursing consultation. The group continues by reporting how they organize work in order to cope with the tension.

N8: So, we [nurse and physician] determined the age range we're going to collect. We collect from women younger than 45 years. (...) she helps me, she already gives medication together with me. (...). (Meeting 2)

New meanings start to appear as possibilities:

N1: Yes, my clinical reflection was in that sense. We can look at our clinical practice through the limit, but we can look at our clinical practice by the power. (Meeting 2)

The group gradually perceives that clinical practice needs to be prioritized, opening room in the work agenda.

N2: I find out that a baby was born (...). I'm gonna visit the baby, ask if everything is OK, because I don't go there just to see the baby. Then I make an appointment for the baby between a week and 10 days later. (...)

N5: I do not manage to schedule it.

N1: I close the agenda for that. I have the courage to close the agenda. It's a priority at the unit. (Meeting 1)

The construction of the amplified clinic as one of the actions constituting the care dimension of nursing work happens in daily reality, in the relation with other practices, in response to the population's health needs. Workers themselves need to understand this social construction process too, however, and the fact that the conquest of this space and the consolidation of their practice depends on them.

\section{Final considerations}

The reflection group meetings carried out a PHE process with the participant nurses, as they permitted analysis and reflection on daily practice itself, exploring its senses in the current context, in the given primary health care conditions.

Clinical practice in the amplified perspective is taking form inside the hegemonic practice, challenging nurses to face the tensions, conflicts, not-knowing, fear, uncertainties, characteristics inherent in primary health care work. The amplified clinic appoints construction in teams and the need to review and redefine the lines demarcating professional activity territories as the route for care.

The study demonstrates the need to create and maintain PHE spaces for nurses to appropriate themselves of their clinical work, constructed in the amplified clinic perspective.

\section{Acknowledgements}

To Professor Maria Cecília Puntel de Almeida, in memoriam, for her active role in the authors' education, and for her review of the research Project this paper resulted from, our eternal gratitude for the learning, daily contact and sharing of so much knowledge.

To Dr. Jorge Bichuetti from Instituto Felix Guatari, a warrior of health and life, and an active producer of utopias, our immense gratitude for his supervision of the group coordinators.

To Fapesp for the research funding.

\section{References}

1. Almeida MCP. O trabalho de enfermagem e sua articulação com o processo de trabalho em saúde coletiva - rede básica de saúde em Ribeirão Preto. [tese livredocência]. Ribeirão Preto (SP): Escola de Enfermagem de Ribeirão Preto/USP; 1991

2. Villa TCS, Mishima SM, Rocha SMM. Os agentes de enfermagem nas práticas sanitárias paulistas: do modelo bacteriológico a programação em saúde (1889-1983). Rev. Latino-Am. Enfermagem. 1994 julho;2(2):73-85.

3. Mishima SM, Almeida MCP, Matumoto S, Pinto IC, Oba MDV, Pereira MJB, et al. A classificação Internacional para a prática de enfermagem em saúde coletiva no Brasil - CIPESC - Apresentando o cenário de pesquisa do município de Ribeirão Preto. In: Chianca TCM, Antunes MJM. A classificação Internacional das Práticas de Enfermagem em Saúde Coletiva - CIPESC. Brasília (DF): ABEn; 1999. p. 204-41. (Série didática; Enfermagem no SUS).

4. Portaria $n^{\circ} 648$ de 28 de março de 2006 (BR). Aprova a Política Nacional de Atenção Básica, estabelecendo a 
revisão de diretrizes e normas para a organização da Atenção Básica para o Programa de Saúde da Família (PSF) e o Programa de Agentes Comunitários de Saúde (PACS). Brasília: Ministério da Saúde; 2006.

5. Silva EM, Nozawa MR, Silva JC, Carmona SAMLD. Práticas das enfermeiras e políticas de saúde pública em Campinas, São Paulo, Brasil. Cad. Saúde Pública. 2001 jul-ago; 17(4):989-98.

6. Peduzzi M. A inserção do enfermeiro na equipe de saúde da família, na perspectiva da promoção da saúde. In: Anais do 10 Seminário Estadual: O enfermeiro no programa de saúde da família; 2000 nov. 9-11; São Paulo. São Paulo: Secretaria de Estado da Saúde; 2000. p. 1-11.

7. Merhy EE. Saúde: a cartografia do trabalho vivo. São Paulo: Hucitec; 2002.

8 Nauderer TM, Lima MAD. Nurses' practices at health basic units in a city in the south of Brazil. Rev. Latino-Am. Enfermagem. 2008 setembro-outubro;16(5):889-94.

9. Santos SMR, Jesus MCP; Amaral AMM, Costa DMN, Arcanjo RA. A consulta de enfermagem no contexto da atenção básica de saúde, Juiz de Fora, Minas Gerais. Texto Contexto Enferm. 2008 jan-mar;17(1):124-30.

10. Ermel RC, Fracolli LA. O trabalho das enfermeiras no programa de saúde da família em Marília/SP. Rev Esc Enferm USP. 2006;40(4):533-9.

11. Maciel ICF, Araujo TL. Consulta de enfermagem: análise das ações junto a programas de hipertensão arterial, em Fortaleza. Rev. Latino-Am. Enfermagem. 2003 março-abril;11(2):207-14.

12. Campos GWS. Clínica e saúde coletiva compartilhadas: teoria Paidéia e reformulação ampliada do trabalho em saúde. In: Campos GWS, Minayo MCS, Akerman M, Drummond M Júnior, Carvalho YM. Tratado de Saúde Coletiva. São Paulo: Hucitec; 2006. p. 53-92.

13. Junges JR, Selli L, Soares NA, Fernandes RBP, Schreck M. Processos de trabalho no Programa Saúde da Família: atravessamentos e transversalidades. Rev Esc Enferm USP. 2009;43(4):937-44.

14. Merhy EE, Feuerwerker LCM, Ceccin RB. Educación Permanente em Salud: uma estratégia para intervenir em la micropolitica del trabajo em salud. Salud Colect.. 2006 mai-ago;2(2):147-60.

15. Baremblitt GF. Compêndio de análise institucional e outras correntes: teoria e prática. 3.ed. Rio de Janeiro: Rosa dos Tempos; 1996.

16. Deleuze G, Guattari F. Mil Platôs: Capitalismo e esquizofrenia, v.3. Rio de Janeiro: Ed. 34; 1999.
17. Passos E, Barros RB. A construção do plano da clínica e o conceito de transdisciplinaridade. Psicol: Teoria Pesqui. 2000 janeiro-abril;16(1):71-9.

18. Coronel LCI. Grupos de reflexão. In: Zimerman DE. Como trabalhamos com grupos. Porto Alegre: Artes Médicas; 1997. p. 345-9.

19. Baremblitt GF. Introdução à esquizoanálise. Belo Horizonte: Instituto Felix Guattari; 1998. 20 Conselho Federal de Enfermagem. Resolução n 272 de 27 agosto de 2002. Dispõe sobre a sistematização da assistência de enfermagem - SAE - nas instituições de saúde brasileiras. Conselho Federal de Enfermagem. Disponível em: http://www.portalcofen.gov.br/2007/materias. asp?ArticleID $=7100$ \&sectionID $=34$

21Ministério da Saúde (BR). Secretaria de Atenção à Saúde. Núcleo Técnico da Política Nacional de Humanização. Clínica ampliada, equipe de referência e projeto terapêutico singular. 2. ed. Brasília: Ministério da Saúde; 2007.

22 Merhy EE, Cecilio LCO. O singular processo de coordenação dos hospitais. Saúde em Debate. 2003 maio-agosto;27(64):110-22.
Received: Out. $14^{\text {th }} 2009$

Accepted: Jul. $16^{\text {th }} 2010$ 